\title{
Yetişkinlerde Sıfatlara Dayalı Kişilik Özellikleri, Otomatik Düşünceler ve Yaşam Doyumlarının İncelenmesi
}

\author{
DOI: 10.26466/opus.681101
}

\author{
Ali Fuat Yalçın* - Betül Karaman ** \\ * Dr.Öğr. üyesi, Necmettin Erbakan Üniversitesi, A.K. Eğitim Fakültesi, Meram/Konya/ Türkiye \\ E-Posta: $\underline{\text { dr alifuatyalcin@yahoo.com ORCID: } 0000-0001-6088-3720}$ \\ ** Y. L. Öğrencisi, Necmettin Erbakan Üniversitesi , Meram/Konya/ Türkiye \\ E-Posta: betulharmankaya@gmail.com ORCID: 0000-0001-8629-3120
}

\section{Öz}

Bu araştırmanın amacl; otomatik düşüncelerin ve sıfatlara dayalı kişilik özelliklerinin, yaşam doyumunu yordayıp yordamadığının incelenmesidir. Bu araştırmada Bacanl, İthan ve Aslan tarafindan geliştirilen Sıfatlara Dayalı Kişilik Testi, Kendall, Howard ve Hays tarafından geliştirilen Otomatik Düşünceler Ölçeği, Diener vd. tarafından yılında geliştirilen Yaşam Doyum Ölçeği kullanılmıştır. Çalışma grubu Necmettin Erbakan Üniversitesi Meram Tıp Fakültesi hastanesi polikliniklerine başvuran ve servislerinde tedavi gören hastalardan oluşmuştur. Katılımcılar; 131'i erkek, 229'u kadın hastadan oluşmaktadır. Yapılan analizlerin sonucunda cinsiyetlere göre yaşam doyumunda ve cinsiyetlere göre kişilik envanteri alt boyutları arasında anlaml farklılı görülmemiştir. Cinsiyetlere göre otomatik düşünceler ölçeğinin olumlu benlik ve yalnızlık/umutsuzluk alt boyutlarında anlamlı farklılık yokken olumsuz benlik ve uyumsuzluk/pişmanlık alt boyutları anlamlı farklılaştığı görülmüştür. Ayrıca;medeni duruma göre yaşam doyumunda anlaml farklllık görülmemiştir. Medeni duruma göre duygusal dengesizlik, dişa dönüklük, deneyime açıklık ve sorumluluk alt boyutlarında anlaml farklllkk yokken, yumuşak başlılık alt boyutunda anlaml farklılı olduğu görülmüştür. Yine, medeni duruma göre otomatik düşünceler ölçeğinin olumsuz benlik, olumlu benlik ve uyumsuzluk/pişmanlık alt boyutlarında anlaml farklilık yokken yalnızlık/umutsuzluk alt boyutu anlamlı düzeyde farklılaştı̆̆ görülmüştür. Yaşam doyumu ile kişilik envanterinin dışa dönüklük, deneyime açıklı, yumuşak başlllık ve sorumluluk alt boyutları arasinda pozitif yönlü, duygusal dengesizlik/nevrotizm alt boyutu arasında ise negatif yönlü anlaml ilişki bulunmuştur. ayrıca; yaşam doyumu ile otomatik düşünceler ölçeğinin olumsuz benlik, yalnızlık/umutsuzluk ve uyumsuzluk/pişmanlık alt boyutları arasında negatif yönlü olumlu benlik alt boyutu arasında ise pozitif yönlü anlamlı ilişki bulunmuştur. Yapılan regresyon analizinde; Duygusal dengesizlik/Nevrotizm kişilik özelliği yaşam doyumunu negatif yönlü; Dışa dönüklük, Deneyime açıklk, Yumuşak başlılık ve Sorumluluk kişilik özellikleri ise pozitif yönlü yordamaktadır. Aynı zamanda yaşam doyumunu Otomatik Düşünceler Ölçeği'nin Olumlu benlik alt boyutu pozitif yönlü, Olumsuz benlik, Yalnızlık/umutsuzluk ve Uyumsuzluk/pişmanlık alt boyutları negatif yönlü yordamaktadır.

Anahtar Kelimeler: Kişilik, otomatik düşünceler, yaşam doyumu, hasta 


\title{
Exmination of Personal Features Based to Adjectives at Adults, Automatic Thoughts and Life Satisfaction
}

\begin{abstract}
The purpose of this study is to examine whether or not automatic thoughts and adjectives based personality predict life satisfaction. In this study, Life Satisfaction Scale, Automatic Thoughts Scale, and Adjective Based Personality Test questionnaires were applied The study group consisted of persons who applied to polyclinics of Meram Faculty of Medicine Hospital, Necmettin Erbakan University. 131 of participants were male and 229 of them were female. As a result of the analyses performed, there was no significant difference between sub-dimensions of life satisfaction according to the genders and personality inventory according to the genders. Besides no significant difference in the positive self-concept and loneliness/hopelessness subscales of the automatic thoughts scale according to gender, it was seen that negative self-concept and incompatibility/regret sub-dimensions differed significantly. There was no significant difference in life satisfaction according to marital status. There was no significant difference in emotional instability (neuroticism), extroversion, openness to experience, and responsibility sub-dimensions according to marital status, there was a significant difference in peacefulness sub-dimension. As a result of the analysis, it was observed that there was no significant difference in negative self-concept, positive self-concept and incompatibility/regret sub-dimensions of automatic thoughts scale, while the loneliness/hopelessness sub-dimension differed significantly. In adition, a significant positive correlation was found between the life satisfaction and the extroversion, openness to experience, peacefulness and responsibility sub-dimensions of personality inventory and a negative correlation was found between emotional instability/neuroticism sub-dimension. Also a negative relationship was found between the life satisfaction and the negative self-concept, loneliness/hopelessness and incompatibility/regret sub-dimensions of automatic thoughts scale and a positive relationship was found between positive self-concept sub-dimension. In the regression analysis performed; Emotional instability/Neuroticism Personality predicts life satisfaction negatively; and extroversion, openness to experience, peacefulness and responsibility personality predict life satisfaction positively. Meanwhile, life satisfaction is positively predicted by the positive self-concept subdimension of Positive Thoughts, negatively predicted by negative self-concept, loneliness/hopelessness and incompatibility/regret sub-dimensions.
\end{abstract}

Keywords: personality, automatic thoughts, liife satisfaction, patient 


\section{Giriş}

Öznel iyi olma; pozitif duygusallık (sevinç, iyimserlik), negatif duygusallık (üzüntü, öfke), belirli alanlardan elde edilen doyum (iş veya ilişkilerden sağlanan doyum) ve genel yaşam doyumu yargılarını içermektedir (Diener vd., 2003). Yaşam doyumunu da içine alan öznel iyi oluş kavramının, bireyin genel olarak yaşamından memnun olmasını, belirli yaşam alanlarından (örn., iş yaşamı, aile hayatı, sağlık, boş zamanlar) hoşnut olmasını, olumlu ve hoşuna giden duyguları (örn. sevinç, coşku, gurur, sevgi, mutluluk) sıklıkla yaşamasını ve kendisini rahatsız eden olumsuz duyguları (öfke, kıskançlık, suçluluk, utanç, üzüntü, kaygı) olumlu duygulara nazaran daha az yaşamasını kapsayan çok boyutlu bir yapı olduğu belirtilmektedir. Bu bağlamda öznel iyi oluşun genel olarak kişinin hayatı ile ilgili yaptığı bilişsel ve duyuşsal değerlendirmeleri kapsadığı; yaşam doyumunun ise, daha çok öznel iyi oluşun bilişsel boyutunu oluşturduğu söylenebilir (Diener, Lucas ve Oishi, 2002, s.63). Kişinin özel hayatına dair kognitif yargısına bağlı bir değerlendirmesidir, öznel iyi olmanın bileşenlerinden birisi olan yaşam doyumu, bilişsel yaklaşıma göre, bireyin kendi yaşamına ilişkin öznel ve bilişsel değerlendirmesidir (Diener, 1984).

Yaşam doyumu bireyin psikolojik durumunu etkileyen çok önemli olgulardan birisidir. Kişinin yaşamında başına gelen pozitif ya da negatif olaylar yaşam kalitesini, dolayısıyla davranışlarını olumlu ya da olumsuz etkilemektedir. Yaşam doyumu ile ortaya çıkan bu durumlar kişilik özellikleri ile de birleştiğinde, bireylerin yaşamlarında önemli tutum ya da davranış değişikliklerine yol açabilmektedir (Özkan, 2013). Bireylerin yaşam doyumlarında en önemli belirleyicilerinden birisi kişilik özellikleridir (Hayes ve Joseph, 2003). Bu kapsamda yaşam doyumu açısından kişilik özellikleri oldukça önem taşımaktadır.

Günümüze kadar pek çok araştırmacı tarafından yüzlerce tanımlama yapılmasına rağmen kişiliğin ne olduğunu tam olarak ifade eden ve herkesçe kabul edilmiş bir kişilik tanımlaması bulunmamaktadır. Bununla birlikte yapılan kişilik tanımları içerisinde en çok kabul gören ve kullanılanlardan biri Gordon Allport'a aittir (Robbins ve Judge, 2013). Allport kişiliği kısaca bireyin çevresine uyum sağlarken kullandığı kendi iç dinamikleri olarak tanımlamıştır. Allporta göre kişilik bir insanın fiziksel ve mental hayatının tamamıdır ve insana ait en özgün şeydir (Allport, 1927). 
Morgan (1991) bireylerin diğer insanların yanlarında sergiledikleri davranış özelliklerinin kişiliği temsil ettiğini belirtmektedir. Kişilik, bireyin özel (characteristic) ve ayırıcı (distinctive) davranışlarını içermektedir. Özeldir, çünkü bireyin sıklıkla yaptığı ya da en tipik davranışlarını temsil eder. Ayırt edicidir, çünkü bu davranışlar kişiyi diğer bireylerden farklı kılmaktadır şeklinde açıklanmaktadır. Kısaca kişilik, bireyin yaşamı süresince, yavaş derecelerle gelişme gösterecek bir tohumdur (Jung, 2005).

Kişilik, gözlenebilir davranışlar üzerine kurulu bir kavramdır, iç ve dış dünyasıyla kişinin oluşturduğu, bireyi diğerlerinden ayıran, dengeli ve kalıplaşmış bir tür bağ şeklinde ifade edilebilir (Cüceloğlu, 2013). Hangi kişilik özelliklerinin ne ölçüde yaşam doyumunda etkili olduğuna yönelik alan yazında pek çok araştırma yapılmıştır. Mutlu ve mutsuz insanlar arasındaki kişilik ve davranış farklarının belirlenmesiyle kişiliğin yaşam doyumunu nasıl etkilediğine ilişkin sorulara yanıt aranmıştır (Şimşek, 2011). Diğer yandan yaşam doyumunu etkileyen bir başka faktör olarak otomatik düşünceler gelmektedir. Beck'e (2015) göre bireyin olaya dair anlık, düşünülmeden ifade bulan yorumları "otomatik düşünce" olarak nitelendirilmektedir. Otomatik düşünceler anlık değerlendirmeler olarak ifade edilebilir. Otomatik düşünceler kişinin öznel ifadeleri ve kendi kendine konuşmaları biçiminde tanımlanmakta ve sorun çözme sürecinde şiddetli bir ters etkiye sahip olmaktadırlar. Kendi kendine konuşmalar açısından bakıldığında, otomatik düşünce kavramı, içsel diyalog olarak da adlandırılmaktadır (Sinanoğlu, 2016). Otomatik düşünceler kişilerin içsel çatışmalarının meydana gelmesine ortam oluşturmakta ve dolaylı olarak kişinin yaşamsal kalitesini negatif şekilde etkilemektedir. Kendi içsel çatısmalarını çözemeyen bir kişinin çevresiyle sağlıklı ilişkiler kurabilmesi de çok mümkün değildir.

Literatürde kişilik özellikleri farklı değişkenlerle birlikte yaşam doyumu açısından ele alınmıştır. Diğer yandan kişilik özellikleri, yaşam doyumu ve otomatik düşünceler kapsamında literatürde araştırma yok denecek kadar azdır. Otomatik düşünceler ve toplum içerisinde kişinin yaşamında önemli bir yere sahip kişilik özellikleri arasındaki ilişkinin incelenmesine yönelik literatürde fazla araştırmanın olmaması bu araştırmanın yapılmasında en önemli etkendir. Literatür incelendiğinde gerek otomatik düşüncelerin yaşam doyumuna etkisi gerekse sıfatlara dayalı kişilik özelliklerinin yaşam doyumunu yordayıp yordamadığına yönelik araştırmaların yok denecek 
kadar az olduğu görülmektedir. Bu açıdan araştırmanın söz konusu alanda büyük bir boşluğu doldurması düşünülmektedir.

\section{Araştırmanın Amacı}

$\mathrm{Bu}$ araştırmada yetişkinlerde; otomatik düşünceler, sıfatlara dayalı kişilik özellikleri ve yaşam doyumu düzeyleri arasındaki ilişkinin incelenmesi amaçlanmıştır. Bu amaç çerçevesinde aşağıdaki alt amaçlara cevap aranmıştir.

\section{Araştırmanın Alt Amaçları}

1. Polikliniklere başvuran ve yataklı servislerde yatmakta olan hastaların yaşam doyumu, kişilik özellikleri ve otomatik düşünceleri cinsiyet değişkenine göre farklılaşmakta mıdır?

2. Polikliniklere başvuran ve yataklı servislerde yatmakta olan hastaların yaşam doyumu, kişilik özellikleri ve otomatik düşünceleri medeni duruma göre farklılaşmakta mıdır?

3. Polikliniklere başvuran ve yataklı servislerde yatmakta olan hastaların yaşam doyumu, kişilik özellikleri ve otomatik düşünceleri arasında anlamlı bir ilişki var mıdır?

4. Polikliniklere başvuran ve yataklı servislerde yatmakta olan hastaların kişilik özellikleri ve otomatik düşünceleri, yaşam doyumunu yordamakta midır?

\section{Yöntem}

$\mathrm{Bu}$ araştırmada betimsel araştırma yöntemlerinden ilişkisel tarama modeli kullanılmıştır.

\section{Çalışma Grubu}

Araştırmanın çalışma grubu, Konya Necmettin Erbakan Üniversitesi Meram Tıp Fakültesi hastanesi dahili ve cerrahi polikliniklerinde aylık ayakta tedavi gören ve servislerde yatan 360 kişiden oluşmaktadır. Katılımcıların, 131 erkek 229 kadındır. Araştırmaya katılan bireylere ait tanımlayıcı istatistikler Tablo 1'de yer almaktadır 
Tablo 1. Katılımcılara Ait Tanımlayıcı İstatistikler

\begin{tabular}{lllll}
\hline & & $\mathbf{n}$ & $\mathbf{\%}$ & yy \\
\hline \multirow{2}{*}{ Cinsiyet } & Erkek & 131 & 36.4 & 36.4 \\
& Kadın & 229 & 63.6 & 100.0 \\
\hline \multirow{4}{*}{ Eğitim } & Okur yazar & 5 & 1.4 & 1.4 \\
Durumu & İkokul & 48 & 13.3 & 14.7 \\
& Ortaokul & 41 & 11.4 & 26.1 \\
& Lise & 110 & 30.6 & 56.7 \\
& Üniversite & 144 & 40.0 & 96.7 \\
Gelir & Lisansüstü & 12 & 3.3 & 100.0 \\
\hline \multirow{2}{*}{ Medeni Durum } & Asgari ücret ve altı & 64 & 17.8 & 17.8 \\
& Asgari ücret - 2000 TL & 96 & 26.7 & 44.4 \\
& 2001-3000 TL & 105 & 29.2 & 73.6 \\
& 3001 TL ve üzeri & 95 & 26.4 & 100.0 \\
\hline
\end{tabular}

Katılımcıların \%36.4'ü erkek, \%63.6'sı kadındır. Eğitim durumu açısından, \%40'1 üniversite, \%30.6's1 lise, \%13.3'ü ilkokul, \%11.4'ü ortaokul, \%3.3'ü lisansüstü, \%1.4 okur-yazar durumdadır. Gelir durum açısından, \%29.2, 2001-3000 TL, \%26.7, Asgari ücret-2000 TL, \%26.4, 3001 TL ve üzeri, $\% 17.8$ asgari ücret ve altında bir gelire sahiptir. Bunların yanında katılımclların \%54.7'si evli, \%45.3'ü bekardır.

\section{Veri Toplama Araçlar}

Araştırmada veri toplamak amacıyla; Öğrencilerin kişilik özelliklerini ölçmek için Bacanll, İlhan ve Aslan tarafından 2009 yılında geliştirilen Sıfatlara Dayalı Kişilik Testi, Kendall, Howard ve Hays (1989) tarafından geliştirilen Otomatik Düşünceler Ölçeği (ODÖ), Diener ve arkadaşları tarafından 1985 yılında geliştirilen Yaşam Doyum Ölçeği (YDÖ) kullanılmıştır.

Yaşam Doyumu Ölçeği (YDO): Araştırmada, Diener ve arkadaşları tarafından 1985 yılında geliştirilen "Yaşam Doyumu Ölçeği" YDÖ - The Satisfaction with Life Scale (SWLS) kullanılmıştır. Yaşam Doyumu Ölçeği, bireylerin yaşamlarından aldıkları doyumu belirlemek amacıyla geliştirilmiştir. Ölçek, likert tarzı 5 dereceli (1: kesinlikle katılmıyorum - 5: Kesinlikle katıllyorum) 5 maddeden oluşmaktadır. Diener ve arkadaşları orijinal çalışmada ölçeğin güvenirliğini Alpha $=.87$ olarak, ölçüt bağımlı geçerliğini ise .82 
olarak bulmuşlardır. Ölçek Dağlı ve baysal (2016) tarafından Türkçeye uyarlanmıştır. Bu çalışmada ölçeğin güvenirliği (Alpha $=.86)$ ve test-tekrar test güvenilirliği .73 olarak bulunmuştur. Yaşam doyumu ölçeğinden alınabilecek en yüksek puan 35, en düşük puan ise 5 'tir. Ölçekten alınan puanın düşük olması yaşam doyumunun düşük olduğunun göstergesi olarak kabul edilmektedir (Kaplan, 2014, s.129). Bu araştırma kapsamında hesaplanan iç tutarlık katsayısı .83 olarak bulunmuştur.

Sıfatlara Dayalı Kişilik Testi (SDKT): Öğrencilerin kişilik özelliklerini ölçmek için Bacanlı, İlhan ve Aslan tarafından (2009) yılında geliştirilen ölçek, beş faktör kişilik kuramında yer alan, duygusal denge (nevrotizm), dışadönüklük, deneyime açıklık, yumuşak başlılık ve sorumluluk alt boyutlarını içermektedir. Bu ölçek zıtlıklardan oluşan 40 sıfat çiftinden oluşmuştur. Bu sıfat çiftinde yanıtlama yöntemi olarak $7^{\text {c } l i ~ l i k e r t ~ d e r e c e l e m e s i ~ k u l l a-~}$ nılmıştır. Yanıtlayıcılardan iki uçta da yer alan sıfatlardan öncelikle hangisinin kendisine uygun olduğunu belirlemesi ve sonrasında ne kadar uyduğunu bulması istenmektedir. Test 1-7 puan arasında değişen sol sütundan sağ sütuna doğru çok uygun, oldukça uygun, biraz uygun, ne uygun ne uygun değil, biraz uygun, oldukça uygun, çok uygun gibi 7 farklı düzeyde derecelendirilmiştir. Her sıfat farklı bir kişilik boyutuna girmektedir. Ölçeğin yapı geçerliliğini elde etmek amacıyla Temel Bileşenler Faktör Analizi yapılmıştır. Analize göre beş faktörün toplam varyansın \%52.63“ünü açıkladığ1 görülmüsstür. Ölçeğin Cronbach alfa iç tutarlılık güvenirlik katsayıları duygusal dengesizlik alt boyutu için .73, dışadönüklük alt boyutu için .89, deneyime açıklık alt boyutu için .80, yumuşak başlılık alt boyutu için .87, sorumluluk alt boyutu için .88 olarak bulunmuştur (Özaydınlık, 2014;110). $\mathrm{Bu}$ araştırma kapsamında hesaplanan iç tutarlık katsayısı katsayıları duygusal dengesizlik alt boyutu için .66, dışadönüklük alt boyutu için .84, deneyime açıklık alt boyutu için .77, yumuşak başlılık alt boyutu için .85, sorumluluk alt boyutu için .78 olarak bulunmuştur.

Otomatik Düşünceler Ölçeği (ODÖ): Otomatik düşünceler ölçeği Kendall, Howard ve Hays tarafından geliştirilmiştir. OTÖ-30'un çeviri ve geçerlik, güvenirlik çalışması Aydın ve Aydın (1990) tarafından yapılııştır. Geliştirilmiş otomatik düşünceler ölçeğine mevcut 30 adet olumsuz cümleye olumlu ve nötr cümlelerin eklenmesi ile olumlu ve olumsuz bilişlerin den- 
gesinin incelenmesi mümkün olmuştur. Depresif deneklerin nötr cümleleri daha olumsuz alıp almadıkları incelenmiştir. (Bozkurt, 1998;115). Ölçeğin faktörleri Olumsuz Benlik Kavramı; 4, 11, 12, 17, 19, 22, 27, 29, 30, 31, 33, 34, 35, 36, 38, 39, 40. Olumlu Benlik Kavrami; 3, 7, 10, 13, 16, 20, 24, 28, 32, 37 . Yalnızlık ve Umutsuzluk; 1, 5, 6, 14, 15, 18, 21. Uyumsuzluk ve Pişmanlık; 2, $8,9,23,25$, 26. sorulardan oluşmaktadır. Ölçeğin geçerliği için depresyon tanısı almış ve almamış kişiler arasında fark incelenmiştir. Depresyon tanısı almış bireylerin yaşam doyum puanları daha düşük bulunmuştur ve bu durum ölçeğin geçerliliğini desteklemektedir. Ölçeğin güvenirliğini incelemek için ölçeğin tamamına ait iç tutarlık katsayısı hesaplanmış ve .95 olarak bulunmuştur. Bu araştırma kapsamında hesaplanan iç tutarlık katsayısı ölçeğin tamamı için .85 iken, Olumsuz Benlik Kavramı alt boyutu için .83, Yalnızlık ve Umutsuzluk alt boyutu için .70 ve Uyumsuzluk ve Pişmanlık alt boyutu için .74 olarak bulunmuştur.

\section{Verilerin Toplanması}

Ölçekler araştırmacıların kendisi tarafından ilgili birimlerde hastalarla yüz yüze görüşülerek uygulanmıştır. Araştırmacılar tarafından hastalara verilen yönergede ve araştırma konusunda yardım ve desteklerine ihtiyaç duyulduğunu, uygulamalardan bir not ya da puan almayacakları belirtilerek, içtenlikle yanıtlamaları konusunda açıklama yapılmıştır.

Toplanan ölçekler ve kişisel bilgi formu araştırmacı tarafından incelenmiş, verilerin değerlendirilmesi ve bilgisayar ortamına girilme işleminde rastgele cevaplandığı ve düzensiz karalamalar yapıldığı görülen 4 ölçek ve kişisel bilgi formu elendikten sonra, kalan 360 ölçek ve kişisel bilgi formu ile araştırmaya devam edilmiştir. Veriler 2018 yılı haziran ve ekim ayları arasinda toplanmiştır.

\section{Verilerin Analizi}

Örneklemi oluşturan hastaların demografik özelliklerini belirlemek amacıyla frekans dağılımları incelenmiş̧tir. Katılımcıların cinsiyet ve medeni durum değişkenlerine göre hastaların yaşam doyumu, otomatik düşünceleri ve kişilik özelliklerinin farklılaşıp farklılaşmadığı bağımsız örneklemler için $\mathrm{t}$ testi ile; hastaların yaşam doyumu, otomatik düşünceleri ve kişilik özellikleri arasındaki ilişki pearson korelasyon analizi ile ve otomatik düşünceler 
ile kişilik özelliklerinin yaşam doyumunun anlamlı bir yordayıcısı olup olmadığı basit doğrusal regresyon analizi incelenmiştir. Araştırmada hata payı 0.05 olarak alınmıştır.

\section{Bulgular}

Bireylerin yaşam doyumu, kişilik özellikleri ve otomatik düşüncelerinin cinsiyet ve medeni durumuna göre farklılaşıp farklılaşmadığına dair bulgular ve yaşam doyumu, kişilik özellikleri ve otomatik düşünceleri arasındaki ilişkiye dair bulgular aşağıda alt başlıklar halinde sunulmuştur..

Yaşam doyumunun cinsiyete göre farklılaşıp farklılaşmadığını öğrenmek için yapılan bağımsız örneklem t testi sonuçları Tablo 2' de yer almaktadir.

Tablo 2. Yaşam Doyumunun Cinsiyete Göre T Testi Sonucu

\begin{tabular}{llllll}
\hline & $\mathbf{n}$ & $\overline{\boldsymbol{x}}$ & Ss & $\mathbf{t}$ & $\mathbf{p}$ \\
\hline Erkek & 131 & 22.16 & 7.09 & -1.688 & .09 \\
Kadin & 229 & 23.34 & 5.96 & & \\
\hline
\end{tabular}

Yapılan analiz sonucunda cinsiyetlere göre yaşam doyumunda anlamlı farklılık görülmemiştir ( $\mathrm{t}=1.688, \mathrm{p}>.05)$.

Kişilik özelliklerinin cinsiyete göre farklılaşıp farklılaşmadı̆̆ını öğrenmek için yapılan bağımsız örneklem t testi sonuçları Tablo 3'de yer almaktadir.

Tablo 3. Kişilik Envanteri Alt Boyutlarnnın Cinsiyete Göre T Testi Sonucu

\begin{tabular}{|c|c|c|c|c|c|c|}
\hline Alt boyutlar & Cinsiyet & $\mathbf{n}$ & $\bar{x}$ & Ss & $t$ & $\mathrm{p}$ \\
\hline \multirow{2}{*}{$\begin{array}{l}\text { Duygusal dengesizlik/ } \\
\text { Nevrotizm }\end{array}$} & Erkek & 131 & 23.73 & 7.61 & \multirow{2}{*}{-.089} & \multirow{2}{*}{.93} \\
\hline & Kadın & 229 & 23.81 & 7.71 & & \\
\hline \multirow{2}{*}{ Dışa Dönüklük } & Erkek & 131 & 43.55 & 10.69 & \multirow{2}{*}{-1.049} & \multirow{2}{*}{.29} \\
\hline & Kadın & 229 & 44.75 & 10.31 & & \\
\hline \multirow{2}{*}{ Deneyime Açıklık } & Erkek & 131 & 38.50 & 9.07 & \multirow{2}{*}{-1.660} & \multirow{2}{*}{.10} \\
\hline & Kadın & 229 & 40.11 & 8.74 & & \\
\hline \multirow{2}{*}{ Yumuşak Başlılık } & Erkek & 131 & 46.81 & 10.76 & \multirow{2}{*}{-1.445} & \multirow{2}{*}{.15} \\
\hline & Kadın & 229 & 48.54 & 11.01 & & \\
\hline \multirow{2}{*}{ Sorumluluk } & Erkek & 131 & 35.80 & 9.06 & \multirow{2}{*}{-1.542} & \multirow{2}{*}{.12} \\
\hline & Kadın & 229 & 37.22 & 7.95 & & \\
\hline
\end{tabular}


Yapılan analiz sonucunda cinsiyetlere göre kişilik envanteri alt boyutları arasında anlamlı farklılık çıkmamıştır ( $\mathrm{p}>$.05).

Otomatik düşüncelerin cinsiyete göre farklılaşıp farklılaşmadığını öğrenmek için yapılan bağımsız örneklem $t$ testi sonuçları Tablo 4 'te yer almaktadır

Tablo 4. Otomatik Düşünceler Ölçeği Alt Boyutlarnnn Cinsiyete Göre T Testi Sonucu

\begin{tabular}{lllllll}
\hline Alt boyutlar & Cinsiyet & $\mathbf{n}$ & \multicolumn{1}{c}{ Ss } & t & p \\
\hline \multirow{2}{*}{ Olumsuz Benlik } & Erkek & 131 & 36.78 & 12.98 & \multirow{2}{*}{2.416} & \multirow{2}{*}{$.02^{*}$} \\
\hline \multirow{2}{*}{ Olumlu benlik } & Kadın & 229 & 33.60 & 11.42 & & \\
& Erkek & 131 & 32.04 & 8.62 & \multirow{2}{*}{-1.758} & \multirow{2}{*}{.08} \\
\hline \multirow{2}{*}{ Yalnızlık/ Umutsuzluk } & Kadın & 229 & 33.66 & 8.33 & & \\
\hline \multirow{2}{*}{ Uyumsuzluk/ Pişmanlık } & Erkek & 131 & 16.18 & 6.03 & \multirow{2}{*}{1.569} & \multirow{2}{*}{.12} \\
& Kadın & 229 & 15.29 & 4.68 & & \multirow{2}{*}{$.00^{*}$} \\
\hline
\end{tabular}
p $<.05$

Yapılan analiz sonucunda cinsiyetlere göre otomatik düşünceler ölçeğinin Olumlu benlik ( $t=-1.758, p>.05)$ ve Yalnızlı/Umutsuzluk ( $t=1.569$, $\mathrm{p}>.05)$ alt boyutlarında anlamlı farklılık yokken Olumsuz benlik ( $\mathrm{t}=2.416$, $\mathrm{p}<.05)$ ve Uyumsuzluk/Pişmanlık $(\mathrm{t}=3.273, \mathrm{p}<.05)$ alt boyutları anlamlı farklılaşmaktadır. Ortalamalara bakıldığında Olumsuz benlik ve Uyumsuzluk/Pişmanlık alt boyutlarında erkeklerin puanının kızlardan daha yüksek olduğu görülmektedir. Bu sonuç erkeklerin kılara göre daha fazla olumsuz benliğe sahip olduğu ve daha fazla uyumsuzluk/pişmanlık yaşadığını göstermektedir.

Yaşam doyumunun medeni duruma göre farklılaşıp farklılaşmadığını öğrenmek için yapılan bağımsız örneklem $t$ testi sonuçları Tablo 5'de yer almaktadır

Tablo 5. Yaşam Doyumunun Medeni Duruma Göre T Testi Sonucu

\begin{tabular}{llllll}
\hline & $\mathbf{n}$ & $\overline{\boldsymbol{x}}$ & Ss & $\mathbf{t}$ & $\mathbf{p}$ \\
\hline Bekar & 163 & 23.43 & 6.07 & 1.350 & \multirow{2}{*}{.18} \\
Evli & 192 & 22.50 & 6.72 & & \\
\hline
\end{tabular}

Yapılan analiz sonucunda medeni duruma göre yaşam doyumunda anlamlı farklılık görülmemiştir ( $t=1.350, \mathrm{p}>.05)$. 
Kişilik özelliklerinin medeni duruma göre farklılaşıp farklılaşmadığını öğrenmek için yapılan bağımsız örneklem t testi sonuçları Tablo 6'da yer almaktadır.

Tablo 6. Kişilik Envanteri Alt Boyutlarnnın Medeni Duruma Göre T Testi Sonucu

\begin{tabular}{|c|c|c|c|c|c|c|}
\hline Alt boyutlar & Medeni D. & $\mathbf{n}$ & $\bar{x}$ & Ss & $\mathbf{t}$ & $\mathbf{p}$ \\
\hline \multirow{2}{*}{$\begin{array}{l}\text { Duygusal dengesizlik/ } \\
\text { Nevrotizm }\end{array}$} & Bekâr & 163 & 24.10 & 7.86 & \multirow{2}{*}{.754} & \multirow{2}{*}{.45} \\
\hline & Evli & 192 & 23.48 & 7.52 & & \\
\hline \multirow{2}{*}{ Dişa Dönüklük } & Bekâr & 163 & 44.06 & 10.47 & \multirow{2}{*}{-.375} & \multirow{2}{*}{.71} \\
\hline & Evli & 192 & 44.48 & 10.43 & & \\
\hline \multirow{2}{*}{ Deneyime Açıklık } & Bekâr & 163 & 39.71 & 8.69 & \multirow{2}{*}{.396} & \multirow{2}{*}{.69} \\
\hline & Evli & 192 & 39.33 & 8.96 & & \\
\hline \multirow{2}{*}{ Yumuşak Başlılık } & Bekâr & 163 & 46.29 & 11.13 & \multirow{2}{*}{-2.564} & \multirow{2}{*}{$.01^{*}$} \\
\hline & Evli & 192 & 49.25 & 10.53 & & \\
\hline Sorumluluk & Bekâr & 163 & 35.89 & 8.11 & -1.687 & .09 \\
\hline
\end{tabular}

Yapılan analiz sonucunda medeni duruma göre Duygusal dengesizlik, Dışa dönüklük, Deneyime açıklık ve Sorumluluk alt boyutlarında anlamlı farklılık yokken ( $\mathrm{p}>.05)$, Yumuşak başlılık alt boyutuna göre anlamlı farklılik bulunmuştur $(\mathrm{t}=-2.564, \mathrm{p}<.05)$.

Otomatik düşüncelerin medeni duruma göre farklılaşıp farklılaşmadığ nı öğrenmek için yapılan bağımsız örneklem t testi sonuçları Tablo 7’de yer almaktadır

Tablo 7. Otomatik Düşünceler Ölçeği Alt Boyutlarının Medeni Duruma Göre T Testi Sonucu

\begin{tabular}{|c|c|c|c|c|c|c|}
\hline Alt boyutlar & Meder & & $\bar{x}$ & Ss & $t$ & $\mathrm{p}$ \\
\hline \multirow{2}{*}{ Olumsuz Benlik } & Bekâr & 163 & 34.47 & 12.65 & -.426 & \multirow{2}{*}{.67} \\
\hline & Evli & 192 & 35.02 & 11.49 & & \\
\hline \multirow{2}{*}{ Olumlu benlik } & Bekâr & 163 & 33.91 & 8.56 & 1.718 & \multirow{2}{*}{.09} \\
\hline & Evli & 192 & 32.37 & 8.26 & & \\
\hline \multirow{2}{*}{ Yalnızlık/ Umutsuzluk } & Bekâr & 163 & 16.17 & 5.65 & 2.007 & \multirow{2}{*}{$.05^{*}$} \\
\hline & Evli & 192 & 15.07 & 4.61 & & \\
\hline \multirow{2}{*}{ Uyumsuzluk/ Pişmanlık } & Bekâr & 163 & 10.76 & 4.73 & -.547 & \multirow{2}{*}{.58} \\
\hline & Evli & 192 & 11.03 & 4.50 & & \\
\hline
\end{tabular}
${ }^{*} \mathrm{p}<.05$

Yapılan analiz sonucunda medeni duruma göre otomatik düşünceler ölçeğinin Olumsuz benlik ( $t=-.426, \mathrm{p}>.05)$, Olumlu benlik $(\mathrm{t}=-1.718, \mathrm{p}>.05)$ ve Uyumsuzluk/pişmanlık ( $\mathrm{t}=-.547, \mathrm{p}>.05)$ alt boyutlarında anlamlı farklılık yokken Yalnızlı/Umutsuzluk $(\mathrm{t}=2.007, \mathrm{p}<.05)$ alt boyutu anlamlı düzeyde 
farklılaşmaktadır. Ortalamalara bakıldığında bekârların yalnızlık/umutsuzluk düzeyi evlilerden daha yüksektir.

Yaşam doyumu ile kişilik özellikleri arasındaki ilişkiyi belirlemek için yapılan pearson momentler çarpım korelasyonu sonuçları Tablo 8'de yer almaktadır

Tablo 8. Yaşam Doyumu İle Kişilik Özellikleri Arasındaki İlişkiye İlişkinKorelasyon Analizi Sonucu

\begin{tabular}{ll}
\hline Kişilik özellikleri & Yaşam doyumu \\
\hline Duygusal dengesizlik/ Nevrotizm & $-191^{* *}$ \\
Dişa Dönüklük & $.209^{* *}$ \\
Deneyime Açıklık & $225^{* *}$ \\
Yumuşak Başllık & $137^{* *}$ \\
Sorumluluk & $.106^{*}$ \\
\hline${ }^{*} \mathrm{p}<.05$ & \\
${ }^{* *} \mathrm{p}<.01$ & \\
\hline
\end{tabular}

Yapılan analizi sonucunda yaşam doyumu ile kişilik envanterinin Dışa dönüklük $(\mathrm{r}=.209, \mathrm{p}<.05)$, Deneyime açıklık $(\mathrm{r}=.225, \mathrm{p}<.05)$, Yumuşak başlılık $(\mathrm{r}=.137, \mathrm{p}<.05)$ ve Sorumluluk $(\mathrm{r}=.106, \mathrm{p}<.05)$ alt boyutları arasinda pozitif yönlü Duygusal dengesizlik/nevrotizm ( $\mathrm{r}=-.191, \mathrm{p}<.05)$ alt boyutu arasinda ise negatif yönlü anlamlı ilişki bulunmuştur.

Yaşam doyumu ile otomatik düşünceler arasındaki ilişkiyi belirlemek için yapılan pearson momentler çarpım korelasyonu sonuçları Tablo 9'da yer almaktadır

Tablo 9. Yaşam Doyumu İle Otomatik Düşünceler Arasındaki İlişkiyi İncelemek Amacryla Yaprlan Korelasyon Analizi Sonucu

\begin{tabular}{ll}
\hline Otomatik düşünceler & Yaşam doyumu \\
\hline Olumsuz Benlik & $-.462^{* *}$ \\
Olumlu benlik & $.364^{* *}$ \\
Yalnızlık/ Umutsuzluk & $-.437^{* *}$ \\
Uyumsuzluk/ Pişmanlık & $-.384^{* *}$ \\
\hline${ }^{*} p<.05$ & \\
${ }^{* *} \mathrm{p}<.01$ & \\
\hline
\end{tabular}

Yapılan analizi sonucunda yaşam doyumu ile otomatik düşünceler ölçeğinin Olumsuz benlik ( $\mathrm{r}=-.462, \mathrm{p}<.05)$, Yalnılık/umutsuzluk $(\mathrm{r}=-.437, \mathrm{p}<.05)$ ve Uyumsuzluk/pişmanlık $(\mathrm{r}=-.384, \mathrm{p}<.05)$ alt boyutları arasında negatif yönlü Olumlu benlik $(\mathrm{r}=.364, \mathrm{p}<.05)$ alt boyutu arasında ise pozitif yönlü anlamlı ilişki bulunmuştur. 
Kişilik özellikleri ile otomatik düşünceler arasındaki ilişkiyi belirlemek için yapılan pearson momentler çarpım korelasyonu sonuçları Tablo 10' da yer almaktadır.

Tablo 10. Otomatik Düşünceler İle Kişilik Özellikleri Arasındaki İlişkiyi İncelemek Amaciyla Yapilan Korelasyon Analizi Sonucu

\begin{tabular}{lllll}
\hline Kişilik Özellikleri & $\begin{array}{l}\text { Olumsuz } \\
\text { Benlik }\end{array}$ & Olumlu benlik & $\begin{array}{l}\text { Yalnızlık/ } \\
\text { Umutsuzluk }\end{array}$ & $\begin{array}{l}\text { Uyumsuzluk/ } \\
\text { Pişmanlık }\end{array}$ \\
\hline $\begin{array}{l}\text { Duygusal dengesizlik/ } \\
\text { Nevrotizm }\end{array}$ & $.276^{* *}$ & $-.225^{*}$ & $.294^{* *}$ & $.143^{* *}$ \\
\hline Dişa Dönüklük & $-.257^{* *}$ & $.312^{* *}$ & $-.223^{* *}$ & $-.297^{* *}$ \\
\hline Deneyime Açıklık & $-.235^{* *}$ & $.245^{* *}$ & $-.200^{* *}$ & $-.305^{* *}$ \\
\hline Yumuşak Başllık & $-.166^{* *}$ & .080 & $-.222^{* *}$ & $-.208^{* *}$ \\
\hline Sorumluluk & $-.226^{* *}$ & $.147^{* *}$ & $-.257^{* *}$ & $-.201^{* *}$ \\
\hline${ }^{*} \mathrm{p}<.05$ & & & \\
${ }^{* *} \mathrm{p}<.01$ & & & & \\
\hline
\end{tabular}

Yapılan analizi sonucunda otomatik düşünceler ölçeğinin Olumsuz benlik alt boyutu ile kişilik envanterinin Dışa dönüklük ( $\mathrm{r}=-.257, \mathrm{p}<.05)$, Deneyime açıklık $(\mathrm{r}=-.235, \mathrm{p}<.05)$, Yumuşak başl11ık $(\mathrm{r}=-.166$, $\mathrm{p}<.05)$ ve Sorumluluk $(\mathrm{r}=.226, \mathrm{p}<.05)$ alt boyutları arasında negatif yönlü Duygusal dengesizlik $(\mathrm{r}=.276, \mathrm{p}<.05)$ alt boyutu arasında pozitif yönlü anlamlı ilişki vardır.

Olumlu benlik alt boyutu ile kişilik envanterinin Dişa dönüklük ( $\mathrm{r}=.312$, $\mathrm{p}<.05)$, Deneyime açıklık $(\mathrm{r}=.245, \mathrm{p}<.05)$ ve Sorumluluk $(\mathrm{r}=.147, \mathrm{p}<.05)$ alt boyutları arasında pozitif yönlü Duygusal dengesizlik $(r=-.225, p<.05)$ alt boyutu arasında negatif yönlü anlamlı ilişki vardır. Olumlu benlik ile yumuşak başlılık arasında anlamlı ilişki yoktur $(\mathrm{r}=.080, \mathrm{p}>.05)$.

Yalnızlık/Umutsuzluk alt boyutu ile kişilik envanterinin Dışa dönüklük $(\mathrm{r}=-.223, \mathrm{p}<.05)$, Deneyime açıklık $(\mathrm{r}=-.200, \mathrm{p}<.05)$, Yumuşak başlılık $(\mathrm{r}=-.222$, $\mathrm{p}<.05)$ ve Sorumluluk $(\mathrm{r}=-.257, \mathrm{p}<.05)$ alt boyutları arasında negatif yönlü Duygusal dengesizlik $(r=.294, p<.05)$ alt boyutu arasında pozitif yönlü anlamlı ilişki vardır.

Uyumsuzluk/pişmanlık alt boyutu ile kişilik envanterinin Dışa dönüklük $(\mathrm{r}=-.297, \mathrm{p}<.05)$, Deneyime açıklık ( $\mathrm{r}=-.305, \mathrm{p}<.05)$, Yumuşak başlılık ( $\mathrm{r}=-.208$, $\mathrm{p}<.05)$ ve Sorumluluk $(\mathrm{r}=-.201, \mathrm{p}<.05)$ alt boyutları arasında negatif yönlü Duygusal dengesizlik ( $\mathrm{r}=.143, \mathrm{p}<.05)$ alt boyutu arasında pozitif yönlü anlamlı ilişki vardır.

Kişilik özellikleri ve otomatik düşüncelerin yaşam doyumunu yordamasına ilişkin basit doğrusal regresyon analizi yapılmıştır. Kişilik özelliklerinin 
yaşam doyumunu yordamasına ilişkin elde edilen bulgular Tablo 11'de yer almaktadır

Tablo 11. Kişilik Özelliklerinin Yaşam Doyumunu Yordamasına İlikin Yapılan Basit Doğrusal Regresyon Sonuçları

\begin{tabular}{lcccccc}
\hline & \multicolumn{2}{l}{ Standart Hata $\beta$} & Standardize $\beta$ & $\mathrm{R}^{2}$ & $\mathrm{t}$ & $\mathrm{p}$ \\
\hline $\begin{array}{l}\text { Duygusal dengesizlik } \\
\text { / Nevrotizm }\end{array}$ & .04 & -.16 & -.19 & .04 & -3.673 & $.00^{*}$ \\
\hline Dişa Dönüklük & .03 & .13 & .21 & .04 & 4.040 & $.00^{*}$ \\
\hline Deneyime Açılık & .04 & .16 & .23 & .05 & 4.371 & $.00^{*}$ \\
\hline Yumuşak Başlılık & .03 & .08 & .14 & .02 & 2.625 & $.01^{*}$ \\
\hline Sorumluluk & .04 & .08 & .11 & .01 & 2.020 & $.04^{*}$ \\
\hline${ }^{*} \mathrm{p}<.05$ & & & & & \\
\hline
\end{tabular}

Tablo 11'de yer alan regresyon analizi sonucunda, Duygusal dengesizlik/Nevrotizm kişilik özelliği yaşam doyumunu negatif yönlü (Standardize $\beta=-.19, \mathrm{p}<.05$ ), Dışa dönüklük (Standardize $\beta=.21, \mathrm{p}<.05$ ), Deneyime açıklık (Standardize $\beta=.23, \mathrm{p}<.05$ ), Yumuşak başlılık (Standardize $\beta=.14, \mathrm{p}<.05$ ) ve Sorumluluk (Standardize $\beta=.11, \mathrm{p}<.05$ ) kişilik özellikleri yaşam doyumunu pozitif yönlü yordamaktadır. Yani, Duygusal dengesizlik- Nevrotizm yaşam doyumunu olumsuz yönde etkilerken; dişa dönüklük, Deneyime açıklık, Yumuşak başlılık ve Sorumluluk yaşam doyumunu olumlu yönde etkilemektedir. Otomatik düşüncelerin yaşam doyumunu yordamasına ilişkin elde edilen bulgular Tablo 12' de yer almaktadır.

Tablo 12. Otomatik Düşüncelerin Yaşam Doyumunu Yordamasına İlişkin Basit Doğrusal Regresyon Analizi Sonuçlarn

\begin{tabular}{|c|c|c|c|c|c|c|}
\hline & Standart Hata & & Standardize $\beta$ & $\mathrm{R}^{2}$ & $\mathrm{t}$ & $\mathrm{p}$ \\
\hline Olumsuz Benlik & .03 & -.25 & -.46 & .21 & -9.858 & $.00^{*}$ \\
\hline Olumlu benlik & .04 & .28 & .36 & .13 & 7.403 & $.00^{*}$ \\
\hline Yalnızlık/ Umutsuzluk & .06 & -.54 & -.44 & .19 & -9.192 & $.00^{*}$ \\
\hline Uyumsuzluk/ Pişmanlık & .07 & -.54 & -.38 & .15 & -7.867 & $.00^{*}$ \\
\hline
\end{tabular}

Tablo 12'de yer alan regresyon analizi sonucunda, yaşam doyumunu, Otomatik Düşünceler Ölçeği'nin Olumlu benlik alt boyutu pozitif yönlü (Standardize $\beta=.36, \mathrm{p}<.05$ ), Olumsuz benlik (Standardize $\beta=-.46$, $\mathrm{p}<.05$ ), Yalnızlık/umutsuzluk (Standardize $\beta=-.44, \mathrm{p}<.05$ ) ve Uyumsuzluk/pişmanlık (Standardize $\beta=-.38, p<.05$ ) alt boyutları negatif yönlü yordamaktadır. Yani Olumsuz benlik, Yalnılık/Umutsuzluk ve Uyumsuzluk/Pişmanlık yaşam 
doyumunu olumsuz yönde etkilerken; Olumlu benlik yaşam doyumunu olumlu yönde etkilemektedir

\section{Tartışma ve Yorum}

\section{Yaşam Doyumu, Kişilik Özellikleri ve Otomatik Düşüncelerin Cinsiyetlere Göre İncelenmesine İlişkin Bulgularnn Tartışma Ve Yorumu}

Bu araştırma kapsamında cinsiyetlere göre yaşam doyumu, kişilik özellikleri ve otomatik düşüncelerinin farklılaşıp farklılaşmadığı incelenmiştir. Araştırma sonucunda cinsiyetlere göre yaşam doyumunda, kişilik özelliklerinde ve otomatik düşüncelerde anlamlı farklılık görülmemiştir.

Bu konuda yapılan araştırmalar incelendiğinde bazı çalışmalarda Gündoğar ve ark., 2007; Tümkaya, 2010; genel yaşam doyumunun cinsiyete göre değişmediği yönünde bulgular elde edilmiştir. Bu bulgular bizim araştırmamızla paralellik gösterirken tam aksi yönde araştırmalarda mevcuttur. Nitekim bazı araştırmalarda ise Tuzgöl Dost ( 2007) genel yaşam doyumunun kızlarda daha yüksek olduğu sonucuna ulaşmışlardır. Diğer yandan Plagnol ve Easterline (2008), yaşam alanlarındaki doyumda cinsiyet farkl1lıklarının ve yaşın rolünü sorgulamıştır. Buna göre; kadınlar yetişkinliklerinin ilk döneminde daha çok finansal doyum ve aile yaşamından doyum sağlamakta olup daha mutludurlar. Kadınlarda 41 yaşında mali doyum, 64 yaşında ise aile doyumu ve 48 yaşında genel mutluluk düzeyi erkeklerle eşitlenmektedir. Bu süreç daha sonra erkeklerin bu alanlardan daha yüksek doyum sağlaması ile devam etmektedir. Erkeklerin yaşam doyumundaki yükselme, gençliklerinde karşılanmayan isteklerinin kadınlardan daha çok olması ve ilerleyen yaşlarda mali durumundaki yükselmesi ile açıklanmaktadır. Kadınlarda ise azalan aile desteği ile birlikte arzuların gerçekleşme oranının düşmesi, düşük doyumun nedeni olarak öne sürülmektedir.

Bunun yanında cinsiyetlere göre otomatik düşünceler ölçeğinin alt boyutları olan Olumsuz benlik ve Uyumsuzluk/pişmanlık alt boyutlarında erkeklerin lehine anlamlı farklılık görülmektedir. Olumlu benlik ve Yalnızlik/umutsuzluk alt boyutlarında farklılık yoktur. Sosyolojik olarak bakıld1ğında erkeklerin aile yaşamında kızlara göre daha özgür bir yapıya sahip olmaları, yaşamda rekabetçi bir ortamda bulunmaları iş yaşamı, sosyal yaşam ve aile yaşamında daha aktif rol aldıklarını belirtmek gerekmektedir. Diğer yandan olumlu benlik ve yalnızlık/umutsuzluk alt boyutunda farkl1- 
laşmamanın ise kadınlar ile erkeklerin yaşam doyumları boyutunda farkl1laşmama ile bağdaşması söylenebilir. Bu sonuçlara bakıldığında cinsiyetlere göre otomatik düşünceler ölçeğinin alt boyutları olan olumlu/olumsuz benlik ve uyumsuzluk/pişmanlık ve yalnızlık/umutsuzluk boyutlarına yönelik literatür bulgusuna rastlanmamıştır.

\section{Yaşam Doyumu, Kişilik ve Otomatik Düşüncelerin Medeni Durumuna Göre İncelenmesine İlişkin Bulguların Tartışma Ve Yorumu}

$\mathrm{Bu}$ araştırma kapsamında medeni durumuna göre yaşam doyumu, kişilik özellikleri ve otomatik düşüncelerinin farklılaşıp farklılaşmadığı incelenmiştir. Araştırma sonucunda medeni durumuna göre yaşam doyumunda anlamlı farklık görülmüştür. Yalnızlık/umutsuzluk alt boyutlarında bekârların puanının evlilerden daha yüksek olduğu görülmektedir. Ortalamalara bakıldığında bekârların yalnızlık/umutsuzluk düzeyi evlilerden daha yüksektir. Yapılan araştırmalarda medeni durumlarının aile üyeleri üzerindeki etkisine bakıldığında, medeni durumun bakım yükünü etkilemediği ancak hastanın bekâr olmasının aile üyelerinde olumsuz otomatik düşünceleri arttırdığı saptanmıştır. Buna göre evlilik bireyin sağlıklı ve mutlu geleceği için bir basamak olarak kabul edilmesinin yanı sıra bakımın devamlılığının sağlanması açısından da bir güvence olarak görülebilmektedir. Bekâr bireylerin aile üyelerinde olumsuz otomatik düşüncelerinin yüksekliği bu durum ile ilişkilendirilebilir

\section{Yaşam Doyumu, Kişilik Özellikleri ve Otomatik Düşünceler Arasındaki İlişkinin İncelenmesine İlişkin Bulguların Tartışma Ve Yorumu}

$\mathrm{Bu}$ araştırma kapsamında yaşam doyumu, kişilik özellikleri ve otomatik düşünceler arasındaki ilişkinin farklılaşıp farklılaşmadığına yönelik ilişki incelenmiştir. Araştırma sonucunda yaşam doyumu ile kişilik özelliklerinden Dışa dönüklük, Deneyime açıklık, Yumuşak başlılık ve Sorumluluk arasında pozitif yönlü, Duygusal dengesizlik/Nevrotizm arasında negatif yönlü anlamlı ilişki bulunmuştur. Yani Dışa dönüklük, Deneyime açklık, Yumuşak başlılık ve Sorumluluk puanı yüksek olan bireylerin yaşam doyumları da yüksektir. Duygusal dengesizliği yüksek olan bireylerin ise yaşam doyumu puanları düşüktür. Yaşam doyumu yüksek bireyler genel olarak daha dışa dönük bireyler olmaktadırlar. Bu durum ise dışa dönük 
kişilerin beyin uyarılma düzeylerinin nispeten daha düşük olduğundan ötürü uyarıcı aramaya daha meyilli oldukları düşünülmektedir. İçe dönük kişiler ise merkezi sinir sistemi uyarılması fazla olduğundan, uyarıcı sosyal çevreden kaçınma eğilimi göstermektedirler. Araştırma sonuçları, beş faktör kişilik modeline ait alt boyutların öznel iyi oluşla farklı düzeylerde ilişkili olduğunu ortaya koymuştur. Yapılan çalışmalarda yaşam doyumunu anlamlı düzeyde yordayan en önemli iki kişilik özelliğinin dışadönüklük ve nevrotiklik olduğu belirlenmiştir. Beş faktör kişilik modeline ait diğer alt boyutlar olan yumuşak başlılık, sorumluluk ve deneyime açıklık alt boyutları ile öznel iyi oluş arasında ise pozitif yönde ancak düşük düzeyde ilişkiler bulunmuştur (DeNeve \& Cooper, 1998; Diener, Lucas ve Oishi, 2002; Eryılmaz ve Öğülmüş, 2010; Furnham ve Cheng, 1997; Lu ve Hu, 2005; McCrae ve Costa, 1991; Dışa dönüklükle öznel iyi oluş arasında pozitif yönde, nevrotiklik ve öznel iyi oluş arasında ise negatif yönde anlamlı ilişkiler bulunmuştur. Dışa dönüklügün özellikle olumlu duygulanımı, nevrotikliğin ise olumsuz duygulanımı yüksek ve anlamlı düzeyde yordadığı belirlenmiştir ( Fujita, Diener ve Sandvik 1991; Lucas ve Fujita, 2000).

Yaşam doyumu ile otomatik düşüneler arasındaki ilişki incelendiği zaman, yaşam doyumu ile Olumsuz benlik, Yalnızlık/Umutsuzluk ve Uyumsuzluk/Pişmanlık arasında negatif yönlü, Olumlu benlik arasında pozitif yönlü anlamlı ilişki bulunmuştur. Yani yaşam doyumu yüksek olan kişilerin olumlu benlik puanları daha yüksek iken, Olumsuz benlik, Yalnızlık/Umutsuzluk ve Uyumsuzluk/Pişmanlık puanları daha düşük bulunmuştur. Yaşam doyumu yüksek olan bireylerin genel olarak yaşam kaliteleri, gelir düzeyleri, sosyalleşmeleri gibi pek çok sebepten dolayı olumlu benlikleri de yükselmektedir. Yapılan bazı araştırmalar, yaşam doyumu yüksek olan üniversite öğrencilerinin farklı rollerine ilişkin daha fazla sorumluluk aldıklarını, romantik ilişki, okul ve aile alanlarındaki doyumlarının daha fazla olduğunu, daha az stres (Bailey ve Miller, 1998) ve daha az duygusal yalnızlık (Çeçen, 2007) yaşadıklarını göstermektedir. Üniversite öğrencileri üzerinde yapılan diğer bazı araştırmalarda da, yaşam doyumu ile benlik saygısı arasında olumlu bir ilişki bulunurken (Yetim, 2003); yaşam doyumunun depresyon, umutsuzluk, durumluk ve sürekli kaygı ile olumsuz ilişkili (Gündoğar vd., 2007) olduğu gözlenmiştir. Dolayısıyla, üniversite öğrencilerinde yaşam doyumunun artmasının, olumlu psikolojik sağlı̆̆ın gerçekleşmesinde dikkate değer bir rol oynadığı söylenebilir. 
Kişilik özellikleri ile otomatik düşünceler arasındaki ilişki incelendiği zaman, Olumsuz benlik, Yalnızlık/Umutsuzluk ve Uyumsuzluk/Pişmanlık alt boyutları ile kişilik özelliklerinden Dışa dönüklük, Deneyime açıklık, Yumuşak başlllık ve Sorumluluk alt boyutları arasında negatif yönlü, Duygusal dengesizlik alt boyutu arasında pozitif yönlü anlamlı ilişki bulunmuştur. Olumlu benlik alt boyutu ile ise Duygusal dengesizlik/Nevrotizm alt boyutu ile negatif yönlü, Dışa dönüklük, Deneyime açıklık ve Sorumluluk alt boyutları arasında pozitif yönlü anlamlı ilişki bulunmuştur. Yani olumlu benliği yüksek olanların dışa dönüklük, deneyime açıklık, yumuşak başlılık ve sorumluluk puanları da yüksek iken olumsuz benlik, yalnızlık/umutsuzluk ve uyumsuzluk/pişmanlık puanı yüksek olan bireylerin duygusal dengesizlik/nevrotizm puanları daha yüksektir. Güngör (2000), bireyin hem mutlu ve başarılı olmasını engelleyen, hem de topluma yararlı olmasını kısıtlayan düşük düzeydeki benlik saygısına sahip olması, kendilerini önemli ve sevilebilir özelliklerden yoksun olarak algıladıklarını; bu kişilerde kendilerine yeteneklerine ve karşısındakilere güvenememe, kolay umutsuzluğa kapılma, sosyal ilişkilerde uyum sağlayamama, çabuk etkilenme, başkalarına bağımlı olma, sık sık suçluluk ve utanç duygularına kapılma gibi kişilik özellikleri görüldügüunü belirtmiştir (Akt; Korkmaz, 2006).. Bu çerçevede yapılan etkinliklerin bireylerin benlik imgelerine olumlu yönde katkı sağlamasının önemli bir sonuç olduğu düşünülmektedir. Bu kapsamda yumuşak başlı, deneyime açık, sorumluluk sahibi bireylerin yaşam doyumu ve otomatik düşünceleri arasında olumlu bir ilişkiden söz edilebilir. Duygusal dengesizliği yüksek olan bireylerin ise yaşam doyumu olumsuzdur.

\section{Kişilik Özelliklerin ve Otomatik Düşüncelerin Yaşam Doyumunu Yordayıp Yordamadığına İlişkin Bulguların Tartışma Ve Yorumu}

Bu araştırma kapsamında kişilik özellikleri ve otomatik düşüncelerin yaşam doyumunu yordayıp yordamadığı incelenmiştir. Araştırma sonucunda kişilik özellikleri, duygusal dengesizlik/Nevrotizm kişilik özelliği negatif yönlü, Dışa dönüklük, Deneyime açıklık, Yumuşak başlılık ve Sorumluluk kişilik özellikleri pozitif yönlü yordamakta olduğu görülmüştür. Ayrıca yaşam doyumunu, ODÖ'nin olumlu benlik alt boyutu pozitif yönlü, olumsuz benlik, yalnızlı/umutsuzluk ve uyumsuzluk/pişmanlık alt boyutları 
negatif yönlü yordadı̆̆ı görülmüş̧tür. Tümkaya ve dig. (2010) yaptıkları araştırma sonucunda ise boyun eğici davranışlar ile otomatik düşünceler ve umutsuzluk arasında pozitif yönde anlamlı ancak düşük bir ilişki olduğu görülmüştür. Otomatik düşünceler ile umutsuzluk arasında pozitif yönde, yaşam doyumu ile arasında ise negatif yönde ve orta düzeyde bir ilişki bulunmuştur. Umutsuzluk ile yaşam doyumu arasında negatif yönde ve orta düzeyde bir ilişki olduğu anlaşılmıştır. Buna göre bireylerin olumlu düşünceleri arttıkça yaşam doyumları artmakta, yaşam doyumlarının artması ise otomatik düşünceleri azaltmaktadır.. Literatürde, psikobiyolojik kişilik modeli ile otomatik düşüncelerin ilişkisini inceleyen çalışma olmasa da KopalaSibley ve Santor (2009)'un başka bir kişilik modeli ile yaptıkları çalışma bulunmaktadır. Bu araştırmada, depresyon için risk faktörleri arasında değerlendirilen aşırı öz-eleştiri kişilik özelliği ile otomatik düşünceler arasında pozitif korelasyon olduğu görülmüsstür. Buna göre, kişilik özelliklerinin, bir şekilde otomatik düşüncelerle ilişkili olduğu söylenebilir.

\section{Sonuç ve Öneriler}

Bu araştırma kapsamında öncelikle cinsiyet ve medeni durum değişkenlerine göre hastaların yaşam doyumu, otomatik düşünceleri ve kişilik özelliklerinin farklılaşıp farklılaşmadığı bağımsız örneklemler için t testi ile incelenmiştir. Daha sonra hastaların yaşam doyumu, otomatik düşünceleri ve kişilik özellikleri arasındaki ilişki pearson korelasyon analizi ile incelenmiştir. Son olarak; yaşam doyumunun bir yordayıcısı olarak otomatik düşünceler ve kişilik özellikleri regresyon analizi ile incelenmiştir. Yapılan analizlerin sonucunda cinsiyetlere göre yaşam doyumunda ve cinsiyetlere göre kişilik envanteri alt boyutları arasında anlamlı farklılık görülmemiştir. Cinsiyetlere göre otomatik düşünceler ölçeğinin olumlu benlik ve yalnızlık/umutsuzluk alt boyutlarında anlamlı farklılık yokken olumsuz benlik ve uyumsuzluk/pişmanlık alt boyutları anlamlı farklılaştığı görülmüştür. Yapılan analiz sonucunda medeni duruma göre yaşam doyumunda anlamlı farklılık görülmemiştir. Yapılan analiz sonucunda; medeni duruma göre duygusal dengesizlik, dişa dönüklük, deneyime açıklık ve sorumluluk alt boyutlarında anlamlı farklılık yokken, yumuşak başlılık alt boyutunda anlamlı farklılık olduğu görülmüştür. Yapılan analiz sonucunda medeni duruma göre otomatik düşünceler ölçeğinin olumsuz benlik, olumlu benlik ve 
uyumsuzluk/pişmanlık alt boyutlarında anlamlı farklılık yokken yalnızlık/umutsuzluk alt boyutu anlamlı düzeyde farklılaştığı görülmüştür. Yapılan analizi sonucunda yaşam doyumu ile kişilik envanterinin dışa dönüklük, deneyime açılık, yumuşak başlılık ve sorumluluk alt boyutları arasında pozitif yönlü, duygusal dengesizlik/nevrotizm alt boyutu arasında ise negatif yönlü anlamlı ilişki bulunmuştur. Yapılan analizi sonucunda yaşam doyumu ile otomatik düşünceler ölçeğinin olumsuz benlik, yalnılık/umutsuzluk ve uyumsuzluk/pişmanlık alt boyutları arasında negatif yönlü olumlu benlik alt boyutu arasında ise pozitif yönlü anlamlı ilişki bulunmuştur. Yapılan regresyon analizinde; Duygusal dengesizlik/Nevrotizm kişilik özelliği yaşam doyumunu negatif yönlü; Dışa dönüklük, Deneyime açıklık, Yumuşak başlılık ve Sorumluluk kişilik özellikleri yaşam doyumunu pozitif yönlü yordamaktadır. Aynı zamanda yaşam doyumunu Otomatik Düşünceler Ölçeği'nin Olumlu benlik alt boyutu pozitif yönlü, Olumsuz benlik, Yalnızlı/umutsuzluk ve Uyumsuzluk/pişmanlık alt boyutları negatif yönlü yordamaktadır.

Araştırmada elde edilen bu bulgular ışığında aşağıdaki önerilere yer verilmiştir:

- Hastaların yaşam doyumuna yönelik programlar hazırlanıp, tedavi süreçlerini daha rahat atlatmaları sağlanabilir.

- Yatılı servislerde kalan hastaların ihtiyaç uyduklarında tüm gün ulaşabilecekleri psiko-sosyal destek birimleri oluşturulabilir.

- Yalnızlı/umutsuzluk alt boyutlarında bekârların puanının evlilerden daha yüksek olduğu görülmüş bu sebeple gerek bekarlar gerekse evliler üzerine ayrı araştırmalar yapılması önerilebilir

- Yakınlarının da tedavi sürecine dâhil edilip bilinçlendirilmeleri ve destek olmaları sağlanabilir.

Not: Bu çalışma; Betül KARAMAN tarafından Dr. Öğr. Üyesi Ali Fuat YALÇIN danışmanlığında Necmettin Erbakan Üniversitesi, Eğitim Bilimleri Enstitisünde 2019 yılında yapılan yüksek lisans tezinden yararlanılarak oluşturulmuştur. 


\title{
EXTENDED ABSTRACT
}

\section{Exmination of Personal Features Based to Adjectives at Adults, Automatic Thoughts and Life Satisfaction}

\author{
Ali Fuat Yalçın - Betül Karaman \\ Necmettin Erbakan University
}

Life satisfaction is one of the very important phenomena that affect the psychological state of the individual. In experiencing positive or negative events in his life, they affect his behavior positively or negatively. When these behaviors that occur with life satisfaction are combined with their characteristics, the important attitude in individuals' lives also leads to behavioral behaviors. It can be expressed as a cognitive evaluation of how well the individual's life is or how he evaluates his life. Personality traits are one of the most important determinants of life satisfaction of individuals. In this context, personality traits are very important in terms of life satisfaction.

A lot of research has been done in the literature on which personality traits are effective in how much life satisfaction. By determining personality and behavior differences between happy and unhappy people, answers were sought regarding how personality affects life satisfaction.

On the other hand, automatic thoughts come as another factor affecting life satisfaction. Automatic thoughts can be expressed as instant evaluations. Such thoughts, which are formed without any effort or choice, often appear in distorted or exaggerated form. Automatic thoughts create an environment for the internal conflicts of people to occur and indirectly affect the life quality of the person negatively.

In the literature, personality traits have been discussed in terms of life satisfaction with different variables. On the other hand, there is scarcely any research in the literature regarding personality traits, life satisfaction and automatic thoughts. The lack of much research in the literature to examine the relationship between automatic thoughts and personality traits that have an important place in the life of the person is the most important factor in conducting this study. In this study, it was aimed to examine the relations- 
hip between automatic thoughts, personality traits based on adjectives and life satisfaction levels in adults.

The study is of important to determine the relationship between life satisfaction, personality and automatic thoughts in adults. In this study, Life Satisfaction Scale, Automatic Thoughts Scale, and Adjective Based Personality Test questionnaires were applied. In this study, the Self-Reflexive Personality Test developed by Bacanl, İlhan and Aslan in 2009, Kendall, Howard and Hays (1989) developed the Life Satisfaction Scale developed by Diener et al. The population of the study consisted of patients applied to and hospitalized in Internal Medicine and Surgery Polyclinics of Meram Faculty of Medicine Hospital, Konya Necmettin Erbakan University. The study group consisted of 360 persons who applied to internal medicine and surgical polyclinics of Meram Faculty of Medicine Hospital, Konya Necmettin Erbakan University. 131 of participants were male and 229 of them were female.

Within the scope of this study, first of all, it was examined by unpaired $t$ test whether or not life satisfaction, automatic thoughts and personalities differed according to variables of gender and marital status. Then, the relationship between life satisfaction, automatic thoughts and personality of the patients was examined with Pearson correlation analysis. Finally, automatic thoughts and personality were examined as a predictor of life satisfaction by regression analysis. As a result of the analyses performed, there was no significant difference between sub-dimensions of life satisfaction according to the genders and personality inventory according to the genders. While there was no significant difference in the positive self-concept and loneliness/hopelessness subscales of the automatic thoughts scale according to gender, it was seen that negative self-concept and incompatibility/regret sub-dimensions differed significantly. According to the analysis performed, there was no significant difference in life satisfaction according to marital status. As a result of the analysis, while there was no significant difference in emotional instability (neuroticism), extroversion, openness to experience, and responsibility sub-dimensions according to marital status, there was a significant difference in peacefulness sub-dimension. As a result of the analysis, it was observed that there was no significant difference in negative self-concept, positive self-concept and incompatibility/regret subdimensions of automatic thoughts scale, while the loneliness/hopelessness sub-dimension differed significantly. 
As a result of the analysis, a significant positive correlation was found between the life satisfaction and the extroversion, openness to experience, peacefulness and responsibility sub-dimensions of personality inventory and a negative correlation was found between emotional instability/neuroticism sub-dimension. As a result of the analysis, a negative relationship was found between the life satisfaction and the negative self-concept, loneliness/hopelessness and incompatibility/regret sub-dimensions of automatic thoughts scale and a positive relationship was found between positive self-concept sub-dimension. In the regression analysis performed; Emotional instability/Neuroticism Personality predicts life satisfaction negatively; and extroversion, openness to experience, peacefulness and responsibility personality predict life satisfaction positively. Meanwhile, life satisfaction is positively predicted by the positive self-concept sub-dimension of Positive Thoughts, negatively predicted by negative self-concept, loneliness/hopelessness and Incompatibility/regret sub-dimensions.

As a result of the findings, discussions and comments were made and necessary suggestions were given.

\section{Kaynakça / References}

Allport, G. W. (1927). Concepts of trait and personality. Psychological Bulletin, 24(5), 284-293

Aydın, G., ve Aydın, O. (1990). Otomatik düşünceler ölçeğinin geçerlik ve güvenirliği. Psikoloji Dergisi, 7(24), 51-55.

Bacanll, H., İlhan, T. ve Aslan, S. (2009). Beş faktör kişilik kuramına dayalı bir kişilik ölçeğinin geliştirilmesi: Sıfatlara Dayalı Kişilik Testi. Türk Eğitim Bilimleri Dergisi, 7(2), 261-279.

Bailey, R. C., ve Miller, C. (1998). Life satisfaction and life demands in college students. Social Behavior and Personality: An international journal, 26, 51-56.

Beck A. T. (2015). Bilişsel terapi ve duygusal bozukluklar. İstanbul: Litera Yayıncllk Cüceloğlu D. (2013). İnsan ve davranışı, İstanbul: Remzi Kitabevi.

Çeçen, A.R. (2007). Humor styles in predicting loneliness among Turkish university students. Social Behazior and Personality: An international journal, 35, 835-844.

Dağll, A. ve Baysal, N. (2016). Yaşam doyumu ölçeğinin türkçe'ye uyarlanmast: geçerlik ve güvenirlik çalışması. Elektronik Sosyal Bilimler Dergisi , 15(59), 1250-1262.

DeNeve, K. M., ve Cooper, H. (1998). The happy personality: A meta-analysis of 137 personality traits and subjective well-being. Psychological Bulletin, 124(2), 197229. https://doi.org/10.1037/0033-2909.124.2.197 
Diener, E. (1984). Subjective wellbeing, Psychological Bulletin, 95(3) 542-575

Diener, E. (1994). Assesing subjective well-being: progress and opportunities, Social Indicators Research, 31, 103-157.

Diener, E. (2003). Subjective well-being: The science of happiness and a proposal for a national index, American Psychologist, 55(1), 34-43

Diener, E., Emmons, R. A., Laresen, R. J. ve Griffin, S. (1985) The satisfaction with life scale, Journal of Personality Assessment, 49, 71-75

Diener, E., Lucas, R. E., ve Oishi, S. (2002). Subjective wellbeing: The science of happiness and life satisfaction. C. R. Snyder ve S. J. Lopez (Eds.), Handbook of positive psychology, New York: Oxford University pres, 63-73.

Diener, E., Oishi, S. ve Lucas, R. E. (2003). Personality, culture, and subjestive wellbeing: Emotional and Cognitive Evalutions Of life, Anual Riview of Psychology, 54, 403-425

Diener, E., Sandvik, E., Seidlitz, L. ve Diener, M. (1993). The relationship between income and subjective vvcll-being: Rclative or absolutc?, Social Indicators Research, 28, 195-223

Diener, E., Suh, E. M., Lucas, R. E. ve Smith, H. L. (1999). Subjective Wellbeing: Three Decades of Progress, Psychological Bulletin, 125(2),

Eryılmaz, A ; Öğülmüşs, S. (2010). Ergenlikte öznel iyi oluş ve beş faktörlü kişilik modeli. Ahi Evran Üniversitesi Ĕ̆itim Fakültesi Dergisi, 11(3), 189-203

Fujita, F., Diener, E. , ve Sandvik, E. (1991). Gender differences in negative affect and well-being: the case for emotional intensity, Journal of Personality and Social Psychology, 61(3), 427-434.

Furnham, A., ve Cheng, H. (1997). Personality and happiness. Psychological Report https://doi.org/10.2466\%2Fpr0.1997.80.3.761

Gündoğar, D., Gül, S. S., Uşkun, E., Demirci, S., ve Keçeci, D. (2007). Üniversite öğrencilerinde yaşam doyumunu yordayan etkenlerin incelenmesi. Klinik Psikiyatri Dergisi, 10 (1), 14-27

Hayes, N. (2013). Psikolojizi anlamak, Çev. Pınar Şengözer, İstanbul: Optimist Yayınları

Jung, C. Gustav (2005). Kişiliğin gelişimi. (Çev. A. Aydoğan). Kişilik oluşumu ve sorunla$r$, İstanbul: İz Yayıncilik, 205-209

Kaplan, H. (2014) İş doyumu yaşam doyumu ilişkisi. Yüksek Lisans Tezi, Beykent Üniversitesi Sosyal Bilimler Enstitüsü, Hastane ve Sağlık Kurumları Yönetimi Bilim Dall, İstanbul.

Kopala-Sibley, D.C. ve Santor, D. A. (2009). The mediating role of automatic thoughts in the personality-event-affect relationship, Cognitive Behavior Therapy. 38(3), 153-61 · September 2009. 
Korkmaz, S. (2006). Üniversite öğrencilerinde depresyonun yordanmast:sosyo demografik değişkenler, olumsuz yaşam olayları, algilanan beklentiler, Yayınlanmamış Yüksek Lisans Tezi, Mersin Üniversitesi Sosyal Bilimler Enstitüsü, Mersin.

Lu L., ve Hu, C. H.(2005). Personality, leisure experiences and happiness, Journal of Happiness Studies, 6,325-342 https://link.springer.com/journal/10902

Lucas, R. E., ve Fujita, F. (2000). Factors influencing the relation between extraversion and pleasant affect. Journal of Personality and Social Psychology, 79(6), 10391056. https://doi.org/10.1037/0022-3514.79.6.1039

McCrae, R. R., ve Costa, P. T. (1991). Positive and negative valence within the fivefactor model, Journal of Research in Personality, 29, 443-460

Morgan, C. T. (1991). Psikolojizy giriş. Çev. S. Karataş vd., Meteksan, 8. Baskı, Ankara,

Özaydınık, Ş (2014) Evli çiftlerin evlilik uyumu ile kişilik özellikleri ve romantik ilişkilerindeki sosyal ilginin incelenmesi. Marmara Üniversitesi, Sosyal Bilimler Enstitüsü, Yüksek Lisans Tezi, İstanbul.

Özkan Ö. (2013). İnternet kullantmuyla ilgili değişkenlerin cinsiyet, kişilik özellikleri, yaşam doyumu ve bağlanma stilleri açısından incelenmesi. Yayınlanmamış Yüksek Lisans Tezi, Ankara Üniversitesi Sosyal Bilimler Enstitüsü, Ankara:

Plagnol A.C. ve Easterline R. (2008). Aspirations, attainments, and satisfaction: life cycle differences between american women and men Journal of Happiness Studies, 9(4), 601-619

Robbins S. P. ve Judge T. A. (2013). Örgütsel davranıs. (Çev: İ. Erdem). İstanbul: Nobel Akademik Yayıncllk

Schimmack, U., Diener, E. ve Oishi, S. (2002). Life-satisfaction is a momentary judgment and a stable personality characteristic: The use of chronically aecessible and stable sources, Journal of Personality, 70(3), 345-384.

Sinanoğlu B. (2016). Lise son sinf öğrencilerinin depresyon, anksiyete belirtileri ve olumsuz otomatik düşüncelerinin taranması. Üsküdar Üniversitesi Sosyal Bilimler Enstitüsü, İstanbul: Yayınlanmamış Yüksek Lisans Tezi

Şimşek, E. (2011). Örgütsel iletişim ve kişilik özelliklerinin yaşam doyumuna etkileri, Anadolu Üniversitesi Sosyal Bilimler Enstitüsü, Eskişehir: Yayımlanmamış Doktora Tezi

Tuzgöl-Dost, M. (2007). Üniversite öğrencilerinin yaşam doyumunun bazı değişkenlere göre incelenmesi, Pamukkale Üniversitesi Eğitim Fakültesi Dergisi, 2(22), 132143

Tümkaya S., Çelik M. ve Aybek B. (2010). Lise öğrencilerinde boyun eğici davranıslar, otomatik düşünceler, umutsuzluk ve yaşam doyumunun incelenmesi, Ç.Ü. Sosyal Bilimler Enstitüsü Dergisi, 20(2), 77-94 
Yetim, U. (2003). The impacts of individualism/collectivism, self-esteem, and feeling of mastery on life satisfaction among the Turkish university students and academicians. Social Indicators Research, 61(3), 297-317. https://doi.org/10.1023/A:1021911504113

\section{Kaynakça Bilgisi / Citation Information}

Yalçın, A. F. ve Karaman, B. (2020). Yetişkinlerde sıfatlara dayalı kişilik özellikleri, otomatik düşünceler ve yaşam doyumlarının incelenmesi. OPUS-Uluslararası Toplum Araştırmaları Dergisi, 16(Eğitim ve Toplum Özel Sayıs1), 5792-5817. DOI: 10.26466/opus.681101 